\title{
Old Ways and New Fears: Bayanihan and Covid-19
}

\section{Greg Bankoff}

In times of trouble, Filipinos traditionally turn to one another for help. While the citizens of Europe and North America primarily look to the state to provide succor and relief, people in the Philippines rarely have this option or are hesitant to avail themselves of it even if they do. Rather help, when it is needed, comes primarily from the community, one's family, friends, compadres, and neighbors. This form of community assistance is called bayanihan, where the root word signifies place or people as well as one who selflessly serves others, literally a hero. The essence of bayanihan lies in the strength of collective action, how the difficulties that will surely overwhelm the individual may be overcome if faced by the community acting together. Historically Filipinos have met the challenges of daily life in their perilous homeland - both the floods, typhoons, earthquakes, volcanic eruptions and lahars, and the insurgencies, invasions, crime, and poverty—by looking to each other and working together. Security lay in numbers and strength in togetherness. Except, apparently, it no longer does, and Filipinos are told that the same properties that made their communities so resilient in the past have been transformed, in a matter of a few short months, into their greatest vulnerability. Even the term bayanihan has been overtly redefined through legislation and government programs to reflect entirely different purposes.

\section{New Fears}


In the first instance, Covid-19 dictates a new community geography on Filipinos. The virus spreads most effectively in crowded places with scant ventilation, poor sanitation, and where social distancing is not only not possible but also culturally distasteful. It would be hard to find a more apt description of many of the informal housing areas in the country's larger cities and towns. More than three out of ten Filipino families (32.5 percent) live in housing units with a floor area of under 29 square meters, and 63 percent of families live in housing units with a floor area of less than 49 square meters. Only 51 percent of families have a main source of water supply that is piped into their dwellings. A further 26 percent of households use shared or unimproved sanitation facilities, including pit or ventilated latrines, hanging toilets, open sewers, buckets, or some other arrangement (Philippine Statistical Authority 2018, 10, 13, 16). As might be expected, these indicators are to be found predominantly among lower socioeconomic groups in the country. In these urban poor communities where it is hard to maintain social distancing, once the virus has penetrated one individual, it only takes a few days before the entire community becomes infected [Instead of Lasco and San Pedro 2020, we suggest:] (see, e.g., Stand for Truth 2020).

Under these conditions, it is not surprising that the virus finds fertile ground in which to spread. The first confirmed cases of Covid-19 occurred in late January 2020 when a couple from the People's Republic of China (PRC) travelling on vacation in the Philippines reported symptoms of cough and sore throat and were admitted to hospital in Manila. The woman recovered, but the man died. It was the first confirmed Covid-19 death outside of the PRC (Edrada et al. 2020). The first Filipinos to test positive for the virus occurred on 5 March when a 48-year-old man returning from a 
recent travel in Japan experienced chills and a fever. On the same day, a husband and wife without a recent travel history also tested positive and became the first cases of local transmission in the country (WHO 2020a). Since then, the virus has spread, accounting for more than 20,000 confirmed cases and nearly 1,000 deaths by early June. The National Capital Region (NCR), comprising Manila plus sixteen neighboring cities and municipalities including Quezon City, has been hardest hit. As of 4 June, 58 percent of all confirmed cases of Covid-19 and 75 percent of all deaths from the virus were reported from the NCR, though this is also the region where most tests have been completed (WHO 2020b). Anecdotal reports suggest that official figures are underestimates of the true infection and mortality rates, given the government's relatively low testing capacity (currently estimated at 30,000 tests a day) in relation to the country's population of 110 million people (Santos and Umel 2020).

\section{Old Ways}

Filipinos historically have faced dangers and hardships more as an assemblage of local communities than as a nation. In the Philippines, the nation still constitutes a contentious notion, and, in many ways, what the Italians refer to as the piccolo patria (small homeland) remains the basis of much public action and civic cohesion. It is at this level that bayanihan traditionally operates and takes two forms: the more reciprocal tit-for-tat arrangements that organize daily interactions in rural areas, and the more altruistic actions performed in times of neighborhood emergency that may embrace a wider setting. The former includes exchanges of farm labor involved in transplanting, harrowing, and harvesting; feast labor in repayment of work performed; 
construction-related activities to build, maintain, or repair houses; and donations of money and goods given after death or serious personal loss. There are many forms of these dyadic labor exchanges practiced mainly in rural communities across the archipelago that fall under the general rubric of gantihan, where the root word ganti means to reciprocate. Aid of whatever kind required is rendered on the expectation that it will be returned in kind at the appropriate time.

The other kind of traditional bayanihan is of quite a different nature and covers the forms of collective action necessary to combat threats that endanger an entire community or that prove beneficial to all the inhabitants of a village. Emergencies might include firefighting, rebuilding houses after a typhoon, or filling and placing sandbags in a flood. Community improvements may involve repairs to the school, the creation of a basketball court, or the construction of a dam. The assistance rendered on these occasions, however, is short-lived or is limited in scope to a specific project (Eadie and Su 2018, 341). Historical evidence shows that Filipinos have long resorted to just such forms of community endeavor in times of misfortune or to better their situation (Bankoff 2012). Unlike all other forms of help, this type of aid does not require ganti or reciprocity as the recipient is too undefined or the opportunity for tit-for-tat exchange improbably distant. Still, those who do not participate in these collective endeavors are noted, and they may find procuring assistance in the future more difficult (Bankoff 2007).

However, in the present situation, these forms of traditional community coping put people at risk because they are difficult to practice with social distancing and the virus is highly contagious. Whether the reproduction number is high because the infectious dose is low (i.e., few particles are needed for infection) or because infected 
people release a lot of virus into their immediate environment is unclear; but, apart from frequent handwashing, the only other known effective means of limiting the spread of Covid-19 is by maintaining social distancing (Gaglia and Lakdawala 2020).

\section{State-sponsored Bayanihan}

In a bid to contain the spread of the virus, the Philippine government declared a national State of Calamity for six months on 16 March. It also imposed a temporary Enhanced Community Quarantine (ECQ) initially only on Luzon island but subsequently extended to designated high-risk areas (mainly large cities and their surrounding hinterlands) across the archipelago (Official Gazette 2020a, c). Under the ECQ, people's rights to movement were restricted and a mass lockdown instituted: schools were closed, shops were shut, public transport was suspended, mass gatherings were prohibited, and international travel was barred. A work-from-home scheme was introduced, only excluding military personnel and those providing essential frontline health and emergency services. People were confined to their homes, and only a single designated household member was permitted outside to buy essential foods and medicines. The ECQ also instituted strict social distancing protocols where people in public places must observe a one-meter distance from each other.

To deal with the national health emergency, moreover, Pres. Rodrigo Duterte was temporarily invested with special powers subject only to certain Congressional oversight. Such powers have not been sought or granted to any constitutional president of the Philippines since those accorded to Pres. Manuel Quezon in 
December 1941 to prosecute the Pacific War against Japan (Tigno 2020, 5). ${ }^{1}$ While Republic Act 11469 makes provision for emergency monthly subsidies to low income households ( $\mathrm{P} 5,000$ to $\mathbb{P} 8,000)$ and an expanded government program of cash/kind grants to the most vulnerable (Pantawid Pamilyang Pilipino Program), it also grants the president unprecedented authority to intervene directly in the day-to-day running of civil society. Among the powers conferred upon him, he can direct, regulate, or limit the operation of private businesses (hospitals, accommodation, transport, and so on) and take over those that refuse to comply with his directives. He can take measures to protect people from hoarding, profiteering, price manipulation, product deceptions, monopolies, “or other pernicious practices." He can require companies to accept and prioritize contracts for services and materials he deems essential and authorize alternative working arrangements for workers and employees in both the public and private sectors. He has the power to move statutory deadlines and timelines for the filing of official documents, the payment of taxes, and other fees required by law. The president is also permitted to undertake measures to conserve and regulate the distribution and use of power, fuel, energy, and water to ensure their adequate supply. Still more comprehensively, the act also allows him to punish open censure of government actions if he determines such criticism constitutes false information that may lead to feelings of fear, panic, chaos, or confusion (Official Gazette 2020b).

The name officially given to this piece of legislation is the Bayanihan to Heal As One Act. Of course, this is not the first time that a Philippine government has

\footnotetext{
${ }^{1}$ Pres. Ferdinand Marcos declared martial law on 21 September 1972, suspending the 1935 Constitution dissolving the Batasang Pambansa, and assuming both legislative and executive powers. These acts were supposedly later ratified by a more than 90 percent approval vote under the 1973 Philippine Martial Law Referendum (Mijares 1976).
} 
borrowed the term for its own purposes. During martial law (1972-1986), Pres.

Ferdinand Marcos hijacked bayanihan and used the term to promote his corporatist vision of an idealized rural community as part of the New Society ([Marcos] 19761980). The photograph of a group of men carrying a peasant house of bamboo and thatch on poles, as immortalized by the iconic mural of the same name by Carlos "Botong" Francisco in 1962, was used to symbolize this rural idyll and placed ubiquitously on pamphlets and school textbooks to epitomize the national spirit (Duldulao [1982?]). The present government also cloaks its actions through appeals to selfless acts of generosity, people giving assistance without thought of compensation, that it claims are synonymous with the Filipino way (Ang 1979). The "bayanihan spirit" is remorselessly disseminated by state-controlled information outlets such as the Philippine Information Agency, with its offices in all regional and provincial centers, and government agencies such as the Philippine National Volunteer Service Coordinating Agency that assiduously promote volunteerism in society (Philippine National Volunteer Service Coordinating Agency 2020). Even the Asian Development Bank (ADB), headquartered in Metro Manila, has "cashed in" on the term. The ADB calls its US\$5 million rapid emergency supplies provision project to deliver critical food supplies to 55,000 vulnerable households in the capital and neighboring areas, Bayan Bayanihan "based on the traditional Filipino Bayanihan principle of community spirit” (Asian Development Bank 2020a, b).

\section{Bayanihan and the Virus}

Over a comparatively short period of time, only three to four generations, what is meant by bayanihan has morphed from a generic term to describe various forms of 
reciprocal labor exchange in rural areas, to one where it represented a corporatist vision of society and was elevated to a quasi-state ideology, to its present manifestation shaped by the present Covid-19 pandemic. What is meant exactly by bayanihan in these circumstances is a contestable and contested notion. Those on the right claim that the Bayanihan to Heal As One Act only confers upon the president the powers necessary to deal with an unprecedented pandemic, to save Filipinos from mass morbidity and mass mortality, and to provide lifelines for the most vulnerable through cash handouts (Diokno 2020). They can point to the effective lockdown carried out by the authorities in mainland China to control the virus or how Cuba served as the UNDRR model for disaster preparedness (Kirk 2017). To those on the left, President Duterte is using the crisis to impose his own authoritarian vision of government upon society and has "weaponized" the virus to his own ends (Beltran 2020). They cite, as an example, the president's 1 April impromptu television address after a confrontation between the authorities and angry residents in Quezon City demanding food. He ordered the police and military to shoot dead quarantine violators on future occasions, warning protesters: "Do not intimidate the government. Do not challenge the government. You will lose" (Capatides 2020). In this new, virus-inspired rendition of bayanihan, it seems, the meaning of the term is changing once again, away from community reliance and more toward state paternalism, away from collective grassroots action and more toward government-sponsored direction. In the process, the term is losing much of its original meaning and has become just another useful word with which to cloak political posturing.

Filipinos, however, have their own answer to such machinations and their own way of dealing with the virus - humor. Media sources report parents favoring a novel 
first name for their newborns since the lockdown: Covid (Reyes 2020). It seems the virus will last a lifetime for some.

\section{References}

Ang, Gertrudes R. 1979. The bayanihan spirit: Dead or alive? Philippine Quarterly of Culture and Society 7(1-2): 91-93.

Asian Development Bank. 2020a.ADB launches \$5 million project to provide food supplies to Philippine households hard hit by COVID-19. Asian Development Bank, 1 Apr.

https://www.adb.org/news/adb-launches-5-million-project-provide-food-suppli es-philippine-households-hard-hit-covid-19.

- 2020b. For poor Filipinos during the pandemic, Bayan Bayanihan brings food and hope. Asian Development Bank, 4 May.

https://www.adb.org/news/features/hungry-filipinos-during-pandemic-bayan-b ayanihan-brings-food-and-hope.

Bankoff, Greg. 2007. The dangers of going it alone: Social capital and the origins of community resilience in the Philippines. Continuity and Change 22(2): $327-55$.

2012. For the good of the barrio: Community associations and the state in the rural Philippines 1935-1965. In Beyond empire and nation: Decolonizing societies in Africa and Asia, 1930s-1970s, ed. Els Bogaerts and Remco Raben, 167-88. Leiden: KITLV Press. 
Beltran, Michael. 2020. The Philippines' pandemic response: A tragedy of errors. The Diplomat, 12 May. https://thediplomat.com/2020/05/the-philippines-pandemic-response-a-tragedy -of-errors/.

Capatides, Christina. 2020. "Shoot them dead": Philippine President Rodrigo Duterte orders police and military to kill citizens who defy coronavirus lockdown. CBS News, 2 Apr. https://www.cbsnews.com/news/rodrigo-duterte-philippines-president-coronav irus-lockdown-shoot-people-dead/.

Diokno, Benjamin. 2020. The Philippines is fighting the COVID-19 crisis head on: Central Bank governor says arsenal of relief measures will see country through. Nikkei Asian Review, 8 Apr. https://asia.nikkei.com/Opinion/The-Philippines-is-fighting-the-COVID-19-cri sis-head-on.

Duldulao, Manuel. D. [1982?] A century of realism in Philippine art. Manila: Fine Arts Corp.

Eadie, Pauline and Yvonne Su. 2018. Post disaster social capital: Trust, equity, bayanihan and Typhoon Yolanda. Disaster Prevention and Management 27(3): 334-45.

Edrada, Edna M., Edmundo B. Lopez, Jose Benito Villarama, Eumelia P. Salva Villarama, Bren F. Dagoc, Chris Smith, Ana Ria Sayo, Jeffrey A. Verona, Jamie Trifalgar-Arches, Jezreel Lazaro, Ellen Grace M. Balinas, Elizabeth Freda O. Telan, Lynsil Roy, Myvie Galon, Carl Hill N. Florida, Tatsuya Ukawa, Annavi Marie G. Villaneuva, Nobuo Saito, Jean Raphael 
Nepomuceno, Koya Ariyoshi, Celia Carlos, Amalea Dulcene Nicolasora, and Rontgene M. Solante. 2020. First COVID-19 infections in the Philippines: A case report. Tropical Medicine and Health 48(21): 1-7.

Gaglia, Marta and Seema Lakdawala. 2020. What we do and do not know about COVID-19's infectious dose and viral load. The Conversation, 14 Apr. https://theconversation.com/what-we-do-and-do-not-know-about-covid-19s-in fectious-dose-and-viral-load-135991.

Kirk, Emily J. 2017. Alternatives-Dealing with the perfect storm: Cuban disaster management. Studies in Political Economy: A Socialist Review 98(1): 93-103.

Easeo, Gideon and Joshua San Pedro. 2020. The 'covidization' of health care. Philippine Daily Inquirer, 7 June. https://opinion.inquirer.net/130544/the-covidization-of-health-eare.

[Marcos, Ferdinand] 1976-1980. Tadhana: History of the Filipino people. 3 vols. Manila: n.p.

Mijares, Primitivo. 1976. The conjugal dictatorship of Ferdinand Marcos and Imelda Marcos. Manila: Union Square Publishing.

Official Gazette. 2020a. Proclamation 929, Declaring a state of calamity throughout the Philippines due to coronavirus disease 2019. Official Gazette, 16 Mar. https://www.officialgazette.gov.ph/downloads/2020/03mar/20200316-PROC929-RRD.pdf. 2020b. Republic Act 11469, An act declaring the existence of a national emergency arising from the coronavirus 2019 (Covid-19) situation and a national policy in connection therewith, and authorizing the president of the Republic of the Philippines for a limited period and subject to restrictions, to 
exercise powers necessary and proper to carry out the declared national policy and for other purposes. Official Gazette, 24 Mar.

https://www.officialgazette.gov.ph/downloads/2020/03mar/20200324-RA-114 69-RRD.pdf.

2020c. Executive Order 112, Imposing an Enhanced Community Quarantine in high-risk geographical areas of the Philippines and a General Community Quarantine in the rest of the country from 01 May to 15 May 2020, adopting the Omnibus Guidelines on the implementation thereof, and for other purposes. Official Gazette, 30 Apr. https://www.officialgazette.gov.ph/downloads/2020/04apr/2020030-EO-112RRD.pdf.

Philippine National Volunteer Service Coordinating Agency. 2020. Bayanihan in the midst of Covid-19. Philippine Information Agency. https://pia.gov.ph/features/articles/1039301.

Philippine Statistical Authority. 2018. 2017 Annual Poverty Indicators Survey, Final Report. Quezon City: Philippine Statistical Authority.

Reyes, Therese. 2020. Filipinos get creative with coronavirus-inspired baby names. Vice, 24 Mar. https://www.vice.com/en_in/article/pke8y9/filipino-name-trend-baby-coronavi rus-covid-bryant.

Santos, Dennis Jay and Richel V. Umel. 2020. Philippines plans to expand COVID-19 testing. Benar News, 19 May. https://www.benarnews.org/english/news/philippine/test-update-05192020134 728.html. 
Stand for Truth. 2020. Ilang lugar sa Metro Manila, balik-lockdown dahil sa COVID-19! Facebook, 18 June. https://www.facebook.com/watch/?v=685700608877007\&t=0.

Tigno, Jorge, ed. 2020. A primer: Bayanihan to Heal as One Act of 2020: 26 Questions. Department of Political Science, University of the Philippines Diliman, 13 Apr. https://polisci.upd.edu.ph/resources/bayanihan-primer/. World Health Organization. 2020a. Coronavirus disease (Covid-19) Situation Report One, Philippines, 9 Mar. https://www.who.int/philippines/emergencies/covid-19-in-the-philippines/covi d-19-sitreps-philippines.

. 2020b. Coronavirus disease (Covid-19) Situation Report 38, Philippines, 4 June. https://www.who.int/docs/default-source/wpro---documents/countries/philippi nes/emergencies/covid-19/who-phl-sitrep-38-covid-19-4jun2020.pdf?sfvrsn=5 7b0a4b_2.

Greg Bankoff is professor of Environmental History, University of Hull, Cottingham Rd, Hull, East Riding of Yorkshire HU6 7RX, United Kingdom. He works on community resilience and the way societies adapt to hazard as a frequent life experience. For the last twenty-five years, he has focused his research primarily on the Philippines, seeking to understand how societies, both past and present, have learned to normalize risk and the manner in which communities deal with crises through a historical sociological approach. An historical geographer, his extensive publications 
include coauthoring The Red Cross's World Disaster Report 2014: Focusing on Culture and Risk and a companion, coedited volume entitled Cultures and Disasters: Understanding Cultural Framings in Disaster Risk Reduction (2015).

<g.bankoff@hull.ac.uk> 